\title{
Should Science Educators Deal with the Science/Religion Issue?
}

\section{MICHAEL J. REISS}

Institute of Education, University of London, UK

\begin{abstract}
Nor would we be satisfied with a biology teacher who understood the arguments and evidence involved in, say, the National Academy of Sciences' (1984) discussion of evolution, but who, outside of the classroom, subscribed to a creationist view of the origin of species.
\end{abstract}

(Kennedy, 1998: 259)

\section{INTRODUCTION}

I suspect that for many science educators, whether or not they have any religious beliefs themselves, the relationships between science and religion, i.e. the 'science/religion issue', appears somewhat outside the scope of science education. However, a range of factors, including a greater awareness of the benefits of dealing explicitly in the school classroom with the nature of science and the increasing significance of creationism, suggests that this perspective may be too narrow. In this article I begin by examining the nature of science and the nature of religion before looking generally at the ways in which science and religion relate to one another. I then look at a number of case studies the centre on the relationships between science and religion (strictly, theology), including attempts to find mechanisms for divine action in quantum theory and chaos theory, creationism, genetic engineering and the writings of Richard Dawkins. These case studies are chosen both because of their significance in the science/religion debate and because of what they can tell us of the more general issues. Finally, I consider some of 
the pedagogical issues that would need to be considered if the science/religion issue is to be addressed in the classroom.

I conclude that there are increasing arguments in favour of science educators (a term I take to include all those concerned with the teaching or communication of science, including teachers of science in school at both primary (5-7 to 11-13 years of age) and secondary (11-13 to 16-19 years of age) levels as well as those involved in some sectors of informal science teaching, for example in natural history museums) teaching about the science/religion issue. The principal reason for this is to help students (a term I shall use to indicate those being taught, whatever their age and whether their science education is formal or informal) better to learn science. However, such teaching makes greater demands on science educators than has generally been the case. Certain of these demands are identified and some specific suggestions are made as to how a science educator might deal with the science/religion issue. At the same time, this paper is most certainly not intended to be the final word on the subject and I close with some suggestions for further research.

\section{THE NATURE OF SCIENCE}

Readers of this journal are not likely to need a long treatment of the nature of science. However, my argument relies on some agreement as to the nature of science and any treatment of the science/religion issue surely requires an examination of both the nature of science and the nature of religion. I will highlight what I hope are a number of relatively uncontroversial points that are germane to the science/religion issue. Although I have suggested elsewhere that the way in which science is conceptualised (Reiss, 1993) and represented (Reiss, 2002) in schools is generally too narrow, my argument here does not depend on the validity of these suggestions. Here I am searching for consensus not staking a particular claim. 
The phrase 'the nature of science' is used as a shorthand for something like 'how science is done and what sorts of things scientists work on'. It therefore contains two elements: the practice of doing science and the knowledge that results.

\section{What do scientists study?}

It is difficult to come up with a definitive answer to the question "What do scientists study?'. Certain things clearly fall under the domain of science - the nature of electricity, the arrangement of atoms into molecules, and human physiology, to give three examples. However, what about the origin of the universe, the behaviour of people in society, decisions about whether we should build nuclear power plants or go for wind power, the appreciation of music and the nature of love, for example? Do these fall under the domain of science? Although a small proportion of people, including a few prominent scientists, would not only argue 'yes' but maintain that all meaningful questions fall within the domain of science, most people hold that science is but one form of knowledge and that other forms of knowledge complement science.

This way of thinking means that the origin of the universe is also a philosophical or religious question - or simply unknowable; the behaviour of people in society requires knowledge of the social sciences (including psychology and sociology) rather than only of the natural sciences; whether we should go for nuclear or wind power is partly a scientific issue but also requires an understanding of economics, risk and politics; the appreciation of music and the nature of love, while clearly having something to do with our perceptual apparatuses and our evolutionary history, cannot be reduced to science (Reiss, 2005).

While historians tell us that what scientists study changes over time, there are reasonable consistencies: 
- Science is concerned with the natural world and with certain elements of the manufactured world - so that, for example, the laws of gravity apply as much to artificial satellites as they do to planets and stars.

- Science is concerned with how things are rather than with how they should be. So there is a science of gunpowder and in vitro fertilisation without science telling us whether warfare and test-tube births are good or bad.

How is science done?

If it is difficult to come up with a definitive answer to the question 'What do scientists study?' it is even more difficult to come up with a clear-cut answer to the question 'How is science done?'. As is well known, Robert Merton characterised science as open-minded, universalist, disinterested and communal (Merton, 1973). For Merton, science is a group activity: even though certain scientists work on their own, all scientists contribute to a single body of knowledge accepted by the community of scientists. There are certain parallels here with art, literature and music. After all, Leonardo da Vinci, Michelangelo and Raphael all contributed to Renaissance art. But while it makes no sense to try to combine their paintings, science is largely about combining the contributions of many different scientists to produce an overall coherent model of one aspect of reality. In this sense, science is disinterested; in this sense it is (or should be) impersonal.

Of course, individual scientists are passionate about their work and often slow to accept that their cherished ideas are wrong. But science itself is not persuaded by such partiality. While there may be controversy about whether the poems of Ezra Pound or those of T. S. Eliot are better (and the question is somewhat meaningless anyway), time invariably shows which of two alternative scientific theories is nearer the truth. For this reason, scientists are well advised to retain 'open mindedness', always being prepared to change their views in the light of new evidence or better explanatory theories, and 
science itself advances over time. As a result, while some scientific knowledge ('frontier science') is contentious, much scientific knowledge can confidently be relied on: it is relatively certain.

Karl Popper emphasised the falsifiability of scientific theories (Popper, 1934/1972): unless you can imagine collecting data that would allow you to refute a theory, the theory isn't scientific. The same applies to scientific hypotheses. So, iconically, the hypothesis 'All swans are white' is scientific because we can imagine finding a bird that is manifestly a swan (in terms of its anatomy and behaviour) but is not white. Indeed, this is precisely what happened when early white explorers returned from Australia with tales of black swans.

Popper's ideas easily give rise to a view of science in which knowledge accumulates over time as new theories are proposed and new data collected to discriminate between conflicting theories. Much school experimentation in science is Popperian in essence: we see a rainbow and hypothesise that white light is split up into light of different colours as it is refracted through a transparent medium (water droplets); we test this by attempting to refract white light through a glass prism; we find the same colours of the rainbow are produced and our hypothesis is confirmed. Until some new evidence causes it to be falsified, we accept it.

There is much of value in the work of Thomas Merton and Karl Popper but most academics in the field would argue that there is more to the nature of science. Thomas Kuhn made a number of seminal contributions but he is most remembered nowadays by his argument that while the Popperian account of science holds well during periods of normal science when a single paradigm holds sway, such as the Ptolemaic model of the structure of the solar system (in which the Earth is at the centre) or the Newtonian understanding of motion and gravity, it breaks down when a scientific crisis occurs (Kuhn, 1970). At the time of such a crisis, a scientific revolution happens during which a new paradigm, such as the Copernican model of the structure of the solar system or Einstein's theory of relativity, begins to replace 
(initially to co-exist with) the previously accepted paradigm. The central point is that the change of allegiance from scientists believing in one paradigm to their believing in another cannot, Kuhn argues, be fully explained by the Popperian account of falsifiability.

Kunn likens the switch from one paradigm to another to a gestalt switch (when we suddenly see something in a new way) or even a religious conversion. As Alan Chalmers puts it:

There will be no purely logical argument that demonstrates the superiority of one paradigm over another and that thereby compels a rational scientist to make the change. One reason why no such demonstration is possible is the fact that a variety of factors are involved in a scientist's judgment of the merits of a scientific theory. An individual scientist's decision will depend on the priority he or she gives to the various factors. The factors will include such things as simplicity, the connection with some pressing social need, the ability to solve some specified kind of problem, and so on. Thus one scientist might be attracted to the Copernican theory because of the simplicity of certain mathematical features of it. Another might be attracted to it because in it there is the possibility of calendar reform. A third might have been deterred from adopting the Copernican theory because of an involvement with terrestrial mechanics and an awareness of the problems that the Copernican theory posed for it.

(Chalmers, 1999: 115-116)

Kuhn also argued that scientific knowledge is validated by its acceptance in a community of scientists. Often scientists change their views as new evidence persuades them that a previously held theory is wrong. But sometimes they cling obstinately to cherished theories. In such cases, if these scientists are powerful (e.g. by controlling which papers get published in the most prestigious journals), scientific progress may be impeded - until the scientists in question retire or die. 
A useful development of Kuhn's work was provided by Lakatos (1978) who argued that scientists work within research programmes. A research programme consists of a set of core beliefs surrounded by layers of less central beliefs. Scientists are willing to accept changes to these more peripheral beliefs so long as the core beliefs can be defended. So, in biology, we might see in contemporary genetics a core belief in the notion that development proceeds via a set of interactions between the actions of genes and the influences of the environment. At one point, it was thought that the passage from DNA to RNA was unidirectional. Now we know (reverse transcriptase, etc.) that this is not always the case. The core belief (that development proceeds via a set of interactions between the actions of genes and the influences of the environment) remains unchanged but the less central belief (that the passage from DNA to RNA is unidirectional) is abandoned. If you consider that science education should not consider the science/religion issue my hope is that is a peripheral rather than a core belief and that this article will help you change your mind.

The above account of the nature of science portrays science as what John Ziman (2000) has termed 'academic science'. Ziman argues that such a portrayal was reasonably valid between about 1850 and 1950 in European and American universities but that since then we have entered a phase largely characterised by 'post-academic science'. Post-academic science is increasingly transdisciplinary and utilitarian, with a requirement to produce value for money; it is characterised by limits to the growth in the number of scientists; it is more influenced by politics; it is more industrialised; and it is more bureaucratic.

The effect of these changes is to make the boundaries around the city of science a bit fuzzier. It is not to deny that there is a city but to question the absoluteness of the distinction between city and countryside, between monarch and subject, between the judiciary and the executive. Of course, if one accepts the contributions of the social study of science (e.g. Yearley, 2005) one finds these boundaries fuzzier still. As I promised above, my argument does not rely on such a reading of science though someone who is 
persuaded by the 'Strong Programme' within the sociology of scientific knowledge (i.e. the notion that even valid scientific theories are amenable to sociological investigation) is much more likely to accept the worth of science educators considering the importance of religion as one of many factors that influence the way science is practised and scientific knowledge produced.

\section{THE NATURE OF RELIGION}

Although one can argue as to whether there is just one science, it is clear that there are many religions. It is rather difficult to answer the question 'What is the nature of religion?' in a way that satisfies the members of all religions. Nevertheless, the following, derived from Smart (1989) and Hinnells (1991), are generally characteristic of most religions.

Religions have a practical and ritual dimension that encompasses such elements as worship, preaching, prayer, yoga, meditation and other approaches to stilling the self.

The experiential and emotional dimension of religions has at one pole the rare visions given to some of the crucial figures in a religion's history, such as that of Arjuna in the Bhagavad Gita and the revelation to Moses at the burning bush in Exodus. At the other pole are the experiences and emotions of many religious adherents, whether a once-in-a-lifetime apprehension of the transcendent or a more frequent feeling of the presence of God either in corporate worship or in the stillness of one's heart.

All religions hand down, whether orally or in writing, vital stories that comprise the narrative or mythic dimension, for example the story of the six day creation in the Judaeo-Christian scriptures. For some religious adherents such stories are believed literally, for others they are understood symbolically.

The doctrinal and philosophical dimension arises, in part, from the narrative/mythic dimension as theologians within a religion struggle to 
integrate these stories into a more general view of the world. Thus the early Christian church came to its understanding of the doctrine of the Trinity by combining the central truth of the Jewish religion - that there is but one God with its understanding of the life and teaching of Jesus Christ and the working of the Holy Spirit.

If doctrine attempts to define the beliefs of a community of believers, the ethical and legal dimension regulates how believers act. So Sunni Islam has its Five Pillars - Shahada (testimony of faith), Salat (prayer), Zakat (almsgiving), Sawm (fasting) and Hajj (pilgrimage to Mecca) - while Judaism has the Ten Commandments and other regulations in the Torah and Buddhism its Five Precepts.

The social and institutional dimension of a religion relates to its corporate manifestation. For example the Sangha - the order of monks and nuns founded by the Buddha to carry on the teaching of the Dharma - in Buddhism, the umma' - the whole Muslim community - in Islam, and the Church - the communion of believers comprising the body of Christ - in Christianity.

Finally, there is the material dimension to each religion, namely the fruits of religious belief as shown by places of worship (e.g. synagogues, temples and churches), religious artefacts (e.g. Eastern Orthodox icons and Hindu statues) and sites of special meaning (e.g. the river Ganges, Mount Fuji and Eyre's Rock).

This overview of the nature of religion is even shorter than the one I provided for science. It is clear, though, that there can be a number of axes on which the science/religion issue can be examined. For example, the effects of the practical and ritual dimension are being investigated by scientific studies that examine such things as the efficacy of prayer and the neurological consequences of meditation (e.g. Lee \& Newberg, 2005); a number of analyses of religious faith, informed by contemporary understandings of evolutionary psychology, behavioural ecology and sociobiology, examine the possibility or conclude that religious faith can be explained by science (e.g. 
Reynolds \& Tanner, 1983; Hinde, 1999; Dennett, 2006); the narrative/mythic dimension of religion clearly connects (in ways that will be examined below) with scientific accounts of such matters as the origins of the cosmos and the evolution of life; the doctrinal and philosophical dimension can lead to understandings that may agree or disagree with standard scientific ones (e.g. about the status of the human embryo); and the ethical and legal dimension can lead to firm views about such matters as land ownership, usury and euthanasia. Perhaps only the social and institutional and the material dimensions of religion are relatively distinct from the world of science (understand, once again, as the natural sciences rather than more broadly).

As will be discussed in the next section, the relationship between science and religion has changed over the years (Brooke, 1991; Al-Hayani, 2005; Szerszynski, 2005); indeed, the use of the singular, 'relationship', risks giving the impression that there is only one way in which the two relate.

Nevertheless, it seems to me that there are two key issues: one is to do with understandings of reality; the other to do with evidence and authority. Although it is always desperately difficult to generalise (difficult in the sense that one lays oneself open to accusations that one hasn't considered every particular - and yet the alternative is to be submerged in a weight of detail that would surely suffocate all but the most devoted / obsessive of readers), most religions hold that reality consists of more than the objective world and many religions give weight to personal and/or (depending on the religion) institutional authority in a way that science generally strives not to. For example, there is a very large religious and theological literature on the world to come, i.e. life after death, (e.g. Hick, 1976/1985). However, to labour the point, science, strictly speaking, has little or nothing to say about this question, while many religious believers within a particular religion are likely to find the pronouncements on the question of even the most intelligent and spiritual of their present leaders to be of less significance than the few recorded words of their religion's founder(s). 
There is now a very large literature on the relationship between science and religion. Indeed, the journal Zygon specialises in this area (see also Science \& Christian Belief, amongst others). A frequent criticism by those who write in this area (e.g. Roszak, 1994) is of what they see as simplistic analyses of the area by those, often renowned scientists, who write occasionally about it. Indeed, it is frequently argued that the clergy both in the past and nowadays are often far more sympathetic to a standard scientific view on such matters as evolution than might be supposed (e.g. Colburn \& Henriques, 2006).

A particularly thorough historical study of the relationship between science and religion is provided by John Hedley Brooke (1991). Brooke's aim is "to reveal something of the complexity of the relationship between science and religion as they have interacted in the past" (p.321). He concludes:

Popular generalizations about that relationship, whether couched in terms of war or peace, simply do not stand up to serious investigation. There is no such thing as the relationship between science and religion. It is what different individuals and communities have made of it in a plethora of different contexts. Not only has the problematic interface between them shifted over time, but there is also a high degree of artificiality in abstracting the science and the religion of earlier centuries to see how they were related.

(Brooke, 1991: 321)

Perhaps the best known categorisation of the ways in which the relationship between science and religion can be understood is provided by lan Barbour (1990). Barbour, who focuses especially on epistemological assumptions of recent Western authors, identifies four main groupings.

First, there is the relationship of conflict; 'first' simply because it is the first in Barbour's list and first, perhaps, also in the minds of many modernists who do not have a religious faith. Barbour doesn't give a reason for the order of his listing but at least two can be suggested: comprehensibility and familiarity. It is 
both easy and familiar (given Barbour's declared focus on recent Western authors) to see the relationship between science and religion as one of conflict. As, though, one might expect from a professor of science, technology and society giving the Gifford lectures (the result of an 1885 bequest of $£ 80,000$ "for the establishment of a series of lectures dealing with the topic of natural religion" (Gifford lectures, 2006)), Barbour sees limitations in this way of understanding the science/religion issue. As he memorably puts it:

In a fight between a boa constrictor and a wart-hog, the victor, whichever it is, swallows the vanquished. In scientific materialism, science swallows religion. In biblical literalism, religion swallows science. The fight can be avoided if they occupy separate territories or if, as I will suggest, they each pursue more appropriate diets.

(Barbour, 1990: 4)

Barbour's second grouping is independence (e.g. Gould, 1999). Science and religion may be seen as independent for two main reasons: because they use distinctive methods or because they function as different languages. In any event, the result is that each is seen as distinct from the other and as enjoying its own autonomy:

Each has its own distinctive domain and its characteristic methods that can be justified on its own terms. Proponents of this view say there are two jurisdictions and each party must keep off the other's turf. Each must tend to its own business and not meddle in the affairs of the others. Each mode of inquiry is selective and has its limitations.

(Barbour, 1990: 10)

Barbour's third grouping moves beyond conflict and independence to dialogue (cf. Berry, 1988; Watts, 1998; Williams, 2001; Polkinghorne, 2005). As an example of dialogue, Barbour points out how our understanding of astronomy has forced us to ask why the initial conditions were present that allowed the universe to evolve. The point is not that the findings of science require a religious faith - that would be for the wart-hog of religion to swallow the boa 
constrictor of science. Rather the point is that scientific advances can give rise (no claim is made that they do for all people) to religious questions, so that a dialogue ensues.

Barbour's final grouping is one in which the relationship between science and religion is seen to be one of integration (cf. Polkinghorne, 1994; Peacocke, 2001). For example, in natural theology it is held that the existence of God can be deduced from aspects of nature rather than from revelation or religious experience (e.g. Ray, 1691/2005). Natural theology has rather fallen out of favour (but see Polkinghorne, 2006). A more modern version is process theology which rejects a view of the world in which purely natural events (characterised by an absence of divine activity) are interspersed with occasional gaps where God acts. Rather, for process theologians, every event is understood "to be jointly the product of the entity's past, its own action, and the action of God" (Barbour, 1990: 29). Furthermore, God is not the Unmoved Mover of Thomas Aquinas but instead acts reciprocally with the world.

There is a danger in finishing with the model of integration that the impression is given that I consider this is the 'best' model. That is not my intention. Indeed, when I eventually turn to consider pedagogical implications I will argue that there is considerable value in students even-handedly being introduced to a range of models as worthy contenders.

One strand of research within science education that is relevant to the issue of the relationship between science and religion has concerned itself with empirical work on how students of school or college age conceptualise this relationship either in general or with reference to particular topics such as evolution (e.g. Ingram \& Nelson, 2006). Koul (2003), for example, obtained survey data from $49212^{\text {th }}$ grade students and interview data from 53 students of the same age in the western edge of the Himalayas in Chamba district, Himachal Preadesh, India. The survey responses were generally consistent with what Koul regarded as "an idealized view of science" (p.113). For example, $89 \%$ of the students regarded science as 'a systematic study of the 
natural world' with $71 \%$ of them seeing scientific knowledge as 'always objective'. They saw clear differences between science and religion in some respects - for example, $91 \%$ held that 'Scientific theories can be tested' whereas only $24 \%$ held that 'Religious beliefs can be tested', and only $31 \%$ felt that 'Scientific methods should be applied to religion' and even fewer, $21 \%$, that 'Religious methods should be applied to science' - but not in others. For example, $43 \%$ held that 'Scientific outlook requires open mindedness' and $45 \%$ that 'Religious outlook requires open mindedness'.

The interviews in Koul's study, as one might expect, offered "a more subtle and complex picture" (p. 114). In particular, few students saw a clear-cut distinction between science and religion. For example:

During her interview, Amrita (all student names are pseudonyms) stated that scientific theories describe the material aspects of nature while dharmic theories describe principles according to which authentic Hindu life can and should be lived. She developed this statement by saying that science only recognizes the material nature of physical reality whereas Hinduism recognizes physical reality as a symbol of an inexhaustible, transcendental power of Nature. Amrita refers to water, trees, mountains, animals, and earth as entities that communicate and aspect of this transcendental power.

Scientific theories describe properties of liquids, gases, compounds while dharmic theories tell us about beauty and power of nature....science is about usefulness while dharma is about the power of different animals, the powers of gods and goddesses

(Koul, 2003: 116) 
The post-Newtonian advent in the early twentieth century of quantum theory and, later in the same century, of chaos theory has led many to wonder whether within either or both of these two frameworks might lie a space for divine action in a way that does not contradict the scientific worldview in the way that miracles seem to. For almost anyone who does not work professionally within quantum physics, it is exceptionally difficult to understand what is going on that is relevant to the science/religion issue but a core concept is that of determinism, which results from the issue of the relationship of measurement to reality (e.g. Osborn, 2005).

As is well known, in 1927 Heisenberg agued that key physical variables (e.g. the position and momentum of an object) are linked. Measuring the one to a very high degree of precision necessarily means that the other cannot be so precisely determined. Thus far there is not a great deal that is of interest to the non-physicist - the issue appears to be one of epistemology. However:

Heisenberg himself took a more radical view - he saw this limitation as a property of nature rather than an artefact of experimentalism. This radical interpretation of uncertainty as an ontological principle of indeterminism implies that quantum mechanics is inherently statistical it deals with probabilities rather than well-defined classical trajectories. Such a view is clearly inimical to classical determinism.

(Osborn, 2005: 132)

Put somewhat loosely, a number of people have tried to find room for divine action in this indeterminancy. No consensus yet exists as to the validity of this search though, on balance, the current views seems to be that such a search is mistaken for reasons both of theology and of physics. A particularly helpful, though demanding, analysis of both the theology and the physics is provided by Saunders (2002). Beginning with the theology, Saunders draws on the widespread distinction between general and special forms of divine action. In the words of Michael Langford general divine action is "the government of the universe through the universal laws that control or influence nature, man, and 
history, without the need for specific or ad hoc acts of divine will" (Langford, 1981: 11). On the other hand, special divine action is characterised by:

Those actions of God that pertain to a particular time and place in creation as distinct from another. This is a broad category and includes the traditional understanding of 'miracles', the notion of particular providence, responses to intercessionary prayer, God's personal actions, and some forms of religious experience.

(Saunders, 2002: 20)

Oversimplifying considerably, and eliding over a thousand years of theology in the Buddhist, Christian, Jewish, Hindu, Islamic and Sikh traditions, all religions are comfortable with the notion of general divine action but they differ both among and within themselves considerably in their understanding of specific divine action. In particular, many leading theologians (but see Pannenberg, 2006) are uncomfortable with the notion of specific divine action so defined for a number of reasons including the particular problems for the occurrence of suffering that it raises (if suffering can sometimes be averted miraculously, why isn't it always?) and the apparent shortcomings, including capriciousness, suggested by a divine who relies on occasional exercises of supernatural activity to keep things moving along.

Going onto the physics, Saunders is sceptical of attempts to locate the possibility of specific divine action in quantum or chaos theory. The argument here becomes even more technical and depends, in respect of quantum theory, on whether one accepts the standard (Copenhagen) interpretation of reality (in which Schrödinger's cat is either dead or alive before the box is opened) or the more radical interpretation (in which the cat is both dead and alive). In both cases, though, and in the case of chaos theory (sometimes termed 'complexity theory' on the grounds that it deals with systems that are deterministic but unpredictable on the grounds of their exquisite sensitivity to small changes in their initial conditions) Saunders rejects attempts to find opportunities for specific divine activity in the science. 


\section{EVOLUTION AND CREATIONISM}

For reasons that delight some and appall others, creationism is growing in extent and influence, both in the UK and elsewhere. Definitions of creationism vary but about $40 \%$ of adults in the USA and at least $10 \%$ in the UK believe that the Earth is only some 10,000 years old, that it came into existence as described in the early parts of the Bible or the Qu'ran and that the most that evolution has done is to change species into closely related species (see Miller et al. (2006) and enter "creationism evolution poll" into a Search Engine). This understanding of creationism is best described as young-Earth creationism as other versions (including old-Earth creationism and progressive creationism) exist. However, although hard data are in short supply, it is clear that the creationism movement is clearly currently dominated by young-Earth creationists. (Creationism, of whatever sort, is not the same as the belief that there is a creator. Many people hold that the world has such a creator without being creationists.) For a creationist it is possible that the various species of zebra had a common ancestor but this is not the case for zebras, bears and antelopes - still less for monkeys and humans, for birds and reptiles or for fish and fir trees.

Those who advocate intelligent design, a theory that has only really been around since the 1990s but has grown hugely in political influence since then, generally make no reference to the scriptures or a deity in their arguments but maintain that the intricacy of the order we see in the natural world, including at a sub-cellular level, provides strong evidence for the existence of an intelligence behind this. An undirected process, such as natural selection, is held to be inadequate (e.g. Behe, 1996, 2003; Dembski, 1998, 2003; Johnson, 1999).

To an evolutionist, the Earth is some 4600 million years old and all organisms share a common ancestor. Indeed, if you go back far enough, life had its ancestry in inorganic molecules. Furthermore, an evolutionary understanding of the world is fundamental to biology and many other aspects of science. For 
an evolutionist, for us to understand ourselves, the other organisms and the world about us requires an evolutionary perspective (Ayala, 2006).

Creationism, Darwinian evolution and intelligent design can be contrasted by means of a classic example: the mammalian eye. For the creationist, there is, of course, nothing to explain. God can create the human eye, as a whole universe, out of nothing and in no time at all. Darwin (1859), though, was well aware that the mammalian eye, with its fine adaptations and its wonderful fitness for purpose, was a problem for his theory. Darwin was unable to point to a fossil history. Instead he appealed to a variety of organisms alive today that have light-detecting structures that differ hugely in complexity. $\mathrm{He}$ reasoned that we could imagine an eye evolving from a simple predecessor to its present mammalian complexity. For intelligent designers, though, this still leaves open the question of how even a 'simple' light-detecting structure came into being. Intelligent designers maintain that when we look at the biochemistry of the simplest such structures, there is a wealth of intricate detail, a certain 'irreducible complexity', that argues for intelligent design.

Most of the literature on creationism (and/or intelligent design) and evolutionary theory puts them in stark opposition. (Evolutionary theory here and from now on is understood as outlined above; everyone is comfortable with the notion that natural selection and possibly other mechanisms are responsible for small-scale evolutionary change.) Of course, even before the advent of intelligent design, there were non-creationist accounts that attempted to disprove Darwinism (e.g. Macbeth, 1974; Hitching, 1982). From the creationist camp, there are a huge number of books and a number of journals devoted to extolling creationism and execrating evolution. It is easy for scientists and science educators, perhaps especially those with no religious faith, to ignore or dismiss such views as worthless but it is important to recognise the vigour with which they are held. After all, imagine you (assuming you are not a creationist) genuinely believed that the theory of evolution was not only factually incorrect but led to increased immorality and the loss of eternal salvation for anyone who believed it, wouldn't you fight 
passionately against it? For an analysis by an academic psychologist of why creationism is here to stay see Evans (2000).

Evolution is consistently presented in creationist books and articles as illogical (natural selection cannot, on account of the second law of thermodynamics, create order out of disorder; mutations cannot lead to improvements), contradicted by the scientific evidence (e.g. the fossil record shows human footprints alongside animals supposed by evolutionists to be long extinct), the product of special pleading (the early history of life would require life to arise from inorganic matter - a form of spontaneous generation; radioactive dating makes huge assumptions about the constancy of natural processes over aeons of time), the product of those who ridicule the word of God (e.g. Richard Dawkins, Steve Jones) and a cause of a number of social evils (eugenics, Marxism, Nazism, racism) - e.g. Heinze (1973), Hall \& Hall (1975), Watson (1975), White (1978), Hayward (1985), Baker (2003) and articles too many to mention in the journals and other publications of the Biblical Creation Society, the Creation Science Movement and other like-minded organisations.

By and large, creationism has received similarly short shrift from those who accept the theory of evolution. In a fairly early study the philosopher of science Philip Kitcher argued that "in attacking the methods of evolutionary biology, Creationists are actually criticizing methods that are used throughout science" (Kitcher, 1982: 4-5). He concluded that the flat-earth theory, the chemistry of the four elements, and mediaeval astrology "have just as much claim to rival current scientific views as Creationism does to challenge evolutionary biology" (Kitcher, 1982: 5). A more trenchant attack on creationism is provided by geologist lan Plimmer whose book title Telling Lies for God: Reason vs Creationism (Plimmer, 1994) accurately sums up the line he takes. An historical analysis is provided by philosopher of science Michael Ruse (and see Numbers \& Stenhouse, 2000) who, while passionately critiquing creationism and defending evolution, is acerbic about those evolutionists who deride all religious belief and those theologians who are attracted to non-Darwinian understandings of life: 
And given the threat that creationists pose to evolutionists of all kinds, it behoves evolutionists especially to start thinking about working together with Christian evolutionists, rather than apart. For a start, atheists like Dawkins and Coyne might consider taking a serious look at contemporary Christian theology (or the theology of other faiths, for that matter), rather than simply parroting the simplistic, schoolboy travesties of religion on which their critiques are founded. Conversely, Christians like Ward and Rolston might be encouraged to dig more deeply into modern, professional evolutionary biology and to start to get some understanding of its strengths and triumphs before they case around for alternatives like self-organization.

(Ruse, 2005: 274)

Many scientists and others have defended evolutionary biology from creationism - see, for example, the various contributions in Selkirk \& Burrows (1987), Good et al. (1992), Manson (2003) and Jones \& Reiss (in press) and an increasing number of agreed statements by scientists on the teaching of evolution (e.g. Interacademy Panel on International Issues, 2006). The main points that are frequently made are that evolutionary biology is good science in that not all science consists of controlled experiments where the results can be collected within a short period of time; that creationism (including 'scientific creationism') isn't really a science in that its ultimate authority is scriptural and theological rather than the evidence obtained from the natural world; and that an acceptance of evolution is fully compatible with a religious faith, an assertion most often made in relation to Christianity (e.g. Southgate et al., 2005) since it is more obviously true of many other religions - including Hinduism, Buddhism and Judaism - and rather less true of Islam (Mabud, 1991; Negus, 2005). For USA data about scientists' religious beliefs at different times see Larson \& Witham (1999). 
The science/religion issue in biology is so often seen only through the lens of the evolution/creationism issue that it is worth spending some time on a very different issue: the acceptability or otherwise of genetic engineering. The intention here is not to launch into an overview of religious understandings of morality but to show how many religions view creation (used here in a wider sense than in some secular cosmologies to mean both 'the original creation' and 'that which exists today' - and including therefore animals, plants and the environment as well as humans) as having a particular status that has implications for science and technology.

The simplest and a well-established theological response to the question of how humans should relate to the rest of creation is that we should leave well alone:

When you start playing around with genes, you're playing God. I don't think we have enough experience to play God. We need a little humility. It seems to be in short supply these days.

(Brower, 1987/1988: 249)

The difficulty with this argument is that it invites us to raise the question 'What's so special about genetic engineering?' (Reiss \& Straughan, 1996). For the same argument could be raised against any new technology. Scientists and technologists can never guarantee that a new process or product is totally safe.

Of course, specific religious objections to genetic engineering can be raised. Indeed the phrase 'playing God' in the above quotation provides one of them and such fears about human hubris or arrogance in trespassing upon divine territory go back at least as far as the religious beliefs of the Ancient Greeks. These objections will not be answered by extrinsic considerations such as assurances of safety or promises about the ultimate benefits of genetic engineering. Similar objections were raised in the nineteenth century when the first anaesthetics were developed and, of course, some religious believers, notably Christian Scientists, refuse medical help to this day. 
Nevertheless, most other religious believers have reached different views, and nowadays accept the benefits of modern medicine, combining a trust in medicine with their religious faith, and seeing medicine as a gift of God.

Indeed, if 'playing God' includes breeding plants that could never have arisen in the wild, then almost everyone, with the possible exception of some aboriginal tribespeople, either plays God or benefits from someone who has. All of the world's crop plants, to say nothing of domesticated animals, are the products of thousands of years of artificial selection. It is inconceivable that the human race could go back to a pre-agricultural existence. Anyway, 'playing God' cannot be restricted to the domestication of animals and plants. Presumably it must also logically include a tremendous range of human achievements from the synthesis of medical drugs to the invention of electricity.

Traditionally a strong strand within certain religions, particularly Judaism, Christianity and Islam, has viewed the created order as having been created for human ends. In Genesis Adam and Eve are told 'Be fruitful and increase, fill the earth and subdue it, rule over the fish in the sea, the birds of heaven, and every living thing that moves upon the earth' (Genesis 1.28). It is difficult for us to reconstruct with certainty how verses such as this one were first understood. There is little doubt, however, that the understanding that humans were created in 'the image of God' (Genesis 1.27) led many people to feel that they were set over nature and had authority to do with it pretty much as they liked. Certainly, the expectation, particularly within some Christian traditions, of life after death, an immanent Apocalypse and the advent of 'a new heaven and a new earth' (Revelation 21.1) makes it easy for some people to feel that they can ignore the needs of the rest of the created order and simply use this world for their ends. However, the notion that humans can exploit the whole of the rest of the created order for their own ends is relatively uncommon in religions. More commonly, religions agree that humans have, at the very least, a responsibility as to how they use the creation, a view reflected in what is often seen as the creation mandate for responsible stewardship. 
In Hinduism, the world's oldest major religion, all life is sacred. Visnu, as supreme being, endlessly creates the worlds of matter and withdraws it into his existence time after time as the cycle of seasons endlessly repeats itself (Prime, 1992; Chapple, 1994). In the Vedic literatures mother Earth is personified as the goddess Bhumi, or Prithvi, the abundant mother who showers her mercy on her children. It is not surprising that Hinduism views humanity as having a great responsibility towards the Earth:

According to the Isa Upanishad, this planet does not belong to humanity, any more than it belongs to the other species living on it:

Everything in the universe belongs to the Lord. You should therefore only take what is really necessary for yourself, which is set aside for you. You should not take anything else, because you know to whom it belongs.

So long as we treat the planet carefully and take only our share, acknowledging that it and everything else belongs to God, the planet will provide for our needs; but as soon as we try to take nature's gifts without offering anything in return we become no better than thieves.

(Prime, 1992: 32)

In Judaism too there is a strong emphasis on the responsibilities that humans have towards nature. Agricultural land was supposed to lie fallow every seventh year as a "sabbath of sacred rest" (Leviticus 25.4). Further, every fifty years, on the Day of Atonement in the Jubilee Year, all land must return to its original owner. Because the Earth is the Lord's, no one has unconditional land rights (Leviticus 25.23).

It should not be thought that the understanding in Judaism of the need for human stewardship is entirely a modern phenomenon. In the twelfth century of the common era, the Jewish scholar Abraham ibn Ezra said of Psalm 
115.16 ("The heavens are the heavens of the Lord, and he gave the earth to people"):

The ignorant have compared man's rule over the earth with God's rule over the heavens. This is not right, for God rules over everything. The meaning of 'he gave it to the people' is that man is God's steward (paqid - officer or official with special responsibility for a specific task) over the earth, and must do everything according to God's word.

(Rose, 1992: 27)

In Buddhism there is a very strong emphasis on how we should relate to the natural world (Brown, 2004). Although Buddhism exists in many different forms, human responsibility towards the creation is a common theme, though the word 'creation' is somewhat inappropriate as the Buddha taught that there is no creator God as the first cause, because there is no beginning. While Buddhism teaches that humans, unlike other creatures, have the opportunity to realise enlightenment, it does not teach that humanity is superior to the rest of the natural world. Indeed, the doctrine of 'emptiness' in Buddhism, as originally developed by the philosopher Nagarjuna, in asserting that all things are empty simply denies that anything can exist on its own (Batchelor \& Brown, 1992; Grosnick, 1994).

The Chinese Buddhists, in particular, emphasised the intimate connections between all things. This philosophy found a more concrete expression in the Zen tradition. For instance, the Japanese Zen master Dogen says:

It is not only that there is water in the world, but there is a world in water. It is not just water. There is also a world of living things in clouds. There is a world of living things in the air. There is a world of living things in fire. There is a world of living things on earth. There is a world of living things in the phenomenal world. There is a world of living things in a blade of grass. There is a world of living things in one staff. Whenever there is a world of living things, there is a world of Buddha ancestors. You should examine the meaning of this. 
In similar vein the Vietnamese monk and poet Thich Nhat Hanh writes:

When we look at a chair, we see the wood, but we fail to observe the tree, the forest, the carpenter, or our own mind. When we meditate on it, we can see the entire universe in all its interwoven and interdependent relations in the chair. The presence of the wood reveals the presence of the tree. The presence of the leaf reveals the presence of the sun. The presence of the apple blossoms reveals the presence of the apple. Meditators can see the one in many, and the many in one. Even before they see the chair, they can see its presence in the heart of living reality. The chair is not separate. It exists only in its interdependent relations with everything else in the universe. It is because all other things are. If it is not, then all others are not either.

(Thich Nhat Hanh, 1988: 90)

A related theme, that of stewardship, is a significant theme in much of the writing on the environmental in Christianity (Bradley, 1990; WCC, 1990; DeWitt, 1994), Islam (Qur'an 2.204-206; 24.41; 30.30; Khalid \& O'Brien, 1992) and other religions (Smart, 1989; Hinnells, 1991). Narrowly understood, stewardship, as a view of how humans should relate to the rest of the natural world, still implies something of a 'them' (the rest of the natural world) versus 'us' (humans) perspective. However, there is a more holistic view of our relationship to the rest of creation. This relationship can be described as one of mutuality, reflecting the biological understanding that a relationship is mutual if it benefits both partners. The word 'mutuality' is therefore intended to avoid overtones of hierarchy and superiority.

George Herbert (1593-1633), the Anglican priest and poet, saw the relationship of humanity to the rest of the created order as one of a priest to his flock:

Man is the worlds High Priest: he doth present 
The sacrifice for all: while they below

Unto the service mutter an assent, (Providence)

In like vein, Arthur Peacocke has explored related metaphors for our relationship to the rest of creation, including humanity as prophets of creation, lovers of creation or fellow-sufferers with it (Peacocke, 1979).

One reason, then, for rejecting genetic engineering is that it involves too exploitative a view not just of animals but of all of nature. This point is made by K. S. Satagopan:

Nature has its own genetic techniques which is borne by the change from Amoeba to men. But man's attempt to speed up change or to bring about important changes in specific ways and forms is very different. It is violence since it is against ecology. All Indian religions (Jainism, Buddhism and Hinduism) are against violence, implicitly or explicitly. From a theoretical point of view Indian religions cannot have anything favourable to say about genetic engineering.

(Satagopan, pers comm.)

This view echoes Martin Heidegger's argument that in technology we make objects according to some blueprint that we determine. We design things to satisfy our purposes rather than allow our purposes to be affected by, and find creative expression through, the qualities of the objects themselves (Heidegger, 1977). Heidegger's point is even more salutary when applied to genetically engineered organisms.

However, perhaps the most frequent response by religious writers to the issue of genetic engineering is one of caution or hesitancy (e.g. Rollin, 2005), increasingly informed by both theological and scientific analysis (e.g. DeaneDrummond, 1997; Bruce \& Bruce, 1998; Deane-Drummond, 2001). Caroline Berry, for example, writes: 
The issues facing Christians are related ... to the tensions that arise as we discover more of our genetic make up and apply that to the workaday world:

the tension between seeing a person as the sum of their genes and as being someone made in the image of God and for whom Christ died;

the tension between wanting the best for our children and accepting them as they are, with their abilities or disabilities, whether mild or severe - we must continue to see children as gifts from God rather than assets to be acquired;

the tension between the individual and their right to privacy and autonomy and the needs of society as a whole;

tensions between commercial profits, the expense of research and our knowledge that a large proportion of the world's population are in need of food and clean water.

(Berry, 1992, 5-6)

In particular, some people may hesitate about the movement of genes between humans and other species, fearing that this somehow diminishes the distinctiveness of being human. For example, the notion that humans are made imago Dei may cause some with a Christian faith to feel uncomfortable about a technology that may threaten to blur the dividing line between humans and the rest of the created order (Reiss, 2003).

Finally, there are religious writers who accept genetic engineering, though typically with certain specific caveats. Phil Challis writes:

We are co-creators with God, "fearfully and wonderfully made" (Ps139:14). With our finite freedom we are called by Him to act responsibly as we continue the process of genetic manipulation of 
domestic organisms. A theology that emphasises embodiment rather than body-spirit dichotomy, that emphasises becoming rather than immutability as an essential part of God's nature, that emphasises relationship within the web rather than domination from outside the system, such a christian theology may provide a critical framework that can realistically embrace the potential of genetic engineering for good.

(Challis, 1992: 39-40)

Ronald Cole-Turner (1993) has explored the implications of a distinction between humans as co-creators with God - a concept which, he feels, contains a number of difficulties - and humans as participants, through genetic engineering, in redemption. Here redemption is being used in the sense of 'restoration'. The idea is that genetic engineering can help to overcome genetic defects caused by harmful mutations. In this way genetic engineering can help to restore creation to a fuller, richer existence and can, Cole-Turner maintains, play an important role without encroaching on the scope of divine activity.

\section{THE WRITINGS OF RICHARD DAWKINS}

It may appear somewhat unbalanced to highlight one particular author in an article on how science educators should deal with the science/religion issue but in many countries, particularly English-speaking ones, Richard Dawkins' writings have had an especial influence. (At the time of writing, "richard dawkins" in Google generates about 50\% more results than "david cameron" - leader of the official government opposition, the Conservative Party, in the UK - and almost 100 times as many as "johnny wilkinson" - who kicked the drop goal that won England the 2003 Rugby Union World Cup.) His importance for the science/religion issue stems from at least two features: the clarity with which he expounds the power of science; and the increasing vehemence with which he denounces religion. 
For Dawkins, science is a wonderful way of seeing the world. His book Unweaving the Rainbow (Dawkins, 1998) is a celebration of how science helps us to see the world more clearly and in ways that previous generations could not have imagined. In a memorable passage in another of his books, he illustrates this when he writes:

It is raining DNA outside. On the bank of the Oxford canal at the bottom of my garden is a large willow tree, and it is pumping downy seeds into the air. There is no consistent air movement, and the seeds are drifting outwards in all directions from the tree. Up and down the canal, as far as my binoculars can reach, the water is white with floating cottony flecks, and we can be sure that they have carpeted the ground to much the same radius in other directions too. The cotton wool is mostly made of cellulose, and it dwarfs the tiny capsule that contains the DNA, the genetic information. The DNA content must be a small proportion of the total, so why did I say that it was raining DNA rather than cellulose? The answer is that it is the DNA that matters. The cellulose fluff, although more bulky, is just a parachute, to be discarded. The whole performance, cotton wool, catkins, tree and all, is in aid of one thing and one thing only, the spreading of DNA around the countryside. Not just any DNA, but DNA whose coded characters spell out specific instructions for building willow trees that will shed a new generation of downy seeds. Those fluffy specks are, literally, spreading instructions for making themselves. They are there because their ancestors succeeded in doing the same. It is raining instructions out there; it's raining programs; it's raining tree-growing, fluff-spreading, algorithms. That is not a metaphor, it is the plain truth. It couldn't be plainer if it were raining floppy discs.

But Dawkins, as is well known, is not content to laud science. He attacks, and with increasing virulence in recent years, religion (e.g. Dawkins, 2006). In a memorable phrase he has described religion as a 'virus', infecting one mind after another so that it can thrive, careless of the havoc it reeks, indifferent to 
the falsehoods it spreads. Some of his fellow evolutionary biologists have wondered precisely why he is so vehement and there is perhaps at least a hint in an essay he first had published in 1993 and which is reprinted as 'Viruses of the mind' in a book dedicated to his daughter, Juliet, on her eighteenth birthday:
A beautiful child close to me, six and the apple of her father's eye, believes that Thomas the Tank Engine really exists. She believes in Father Christmas, and when she grows up her ambition is to be a tooth fairy. She and her schoolfriends believe the solemn word of respected adults that tooth fairies and Father Christmases really exist. This little girl is of an age to believe whatever you tell her. If you tell her about witches changing princes into frogs, she will believe you. If you tell her that bad children roast forever in hell, she will have nightmares. I have just discovered that without her father's consent this sweet, trusting, gullible six-year-old is being sent, for weekly instruction, to a Roman Catholic nun. What chance has she?

(Dawkins, 1993/2003/2004: 151)

As one might expect, there have been a number of theological responses to Dawkins. Among science educators, Michael Poole has argued that Dawkins misunderstands much of what it is that religions claim and confuses the different meanings of 'explanation' (Poole, 1994, 2002). Among theologians, John Bowker devoted his 1992-93 Gresham lectures to the question 'Is God a Virus?' (Bowker, 1995) - the short answer, for Bowker, is 'No' - while Alister McGrath has written two books on Dawkins' theology (McGrath, 2005; McGrath with McGrath, 2007). Perhaps unsurprisingly from a professor of historical theology, albeit someone with a PhD in molecular biophysics, McGrath finds that Dawkins' writings about religious faith fall far short of his standards when writing about biology. For example, Dawkins is fond of criticising religious faith as 'blind trust' and likening it to belief in Father Christmas or the Tooth Fairy, yet, as McGrath puts it: 
There is no serious empirical evidence that people regard God, Santa Claus, and the Tooth Fairy as being in the same category. I stopped believing in Santa Claus and the Tooth Fairy when I was about six years old. After being an atheist for some years, I discovered God when I was eighteen, and have never regarded this as some kind of infantile regression. As I noticed while researching The Twilight of Atheism, a large number of people come to believe in God in later life - when they are "grown up." I have yet to meet anyone who came to believe in Santa Claus or the Tooth Fairy late in life.

(McGrath, 2005: 87)

It ought, though, to be pointed out that there are extremely large numbers of intelligent, (otherwise) rational and normal USA citizens who have come to believe that as adults they were kidnapped by aliens, painfully experimented on and then returned to Earth (Clancy, 2005).

\section{PEDAGOGICAL ISSUES}

A lot of the science education literature simply treats the science/religion issue as problematic. However, a number of studies have tried to find effective ways of teaching in this area. Perhaps unsurprisingly, most are to do with evolutionary biology though there are some in other areas of science, principally cosmology and geology (e.g. Poole, 1995; Science and Religion in Schools Project, 2006).

Several studies have investigated or advocate the use of role play, one advantage of which is that it can allow one the opportunity to act out another's point of view. Jon Duveen and Joan Solomon used a role play for 15-16 yearolds based on a fictitious trial for blasphemy of On the Origin of Species and note that "Not only do students learn science but they also learn about science" (Duveen \& Solomon, 1994: 581). Similarly, Smith (1994) recommended that the nature of science be explicitly addressed while Bentley (2000) successfully used a simulation/improvisation activity for his own pre- 
service science education students and for in-service workshops based on a fictitious debate at a School Board as to whether evolution should be presented as 'just a theory'. Helgeson et al. (2002) introduced pre-service teachers to issues surrounding evolution and creationism via a mock trial and found gains in students' understanding of evolutionary principles and awareness of the difficulties of balancing evolutionism and creationism in science pedagogy.

Others have emphasised the value of using the evolution/creationism controversy as a way of emphasising science as a process of critical thinking (Skehan \& Nelson, 2000; several contributors to Campbell \& Meyer, 2003). This, of course, requires some consideration of the arguments of creationism which can (and quite often does) lead to alarm among scientists and others, fearful of creationism being 'taught' in science. For example, Clough maintains:

The corollary to the argument for teaching biological evolution is obviously that "scientific" creationism should not be given any credibility in science courses because it is not considered to be good science by the scientific enterprise.

(Clough, 1994: 409)

Other studies entail getting students to discuss whether humans are still evolving (Shields, 2004) and providing high school students with opportunities to reason like evolutionary biologists (Passmore et al., 2005)

One of the most interesting studies is that of Shipman et al. (2002). This study drew on Cobern's worldview theory (Cobern, 1996) and the approach of conceptual ecology (Toulmin, 1972) to develop and implement "a modest inclusion of science and religion" (p.530) in a college astronomy course at the University of Delaware. The general approach of the instructor (Harry Shipman) was: 
To recognize that students may be coming at this issue from a diversity of religious viewpoints ... his basic approach to the issue [was] one of humility, of tolerance of as many religious viewpoints as is possible, given the constraints of the scientific evidence ... He publicly acknowledged that many theistic scientists can believe in God, evolution, and the Big Bang at the same time, and he briefly discussed the consequences of such a belief.

(Shipman et al., 2002, p.530)

As one might expect, the students differed greatly both before and after the course in terms of how they saw the science/religion issue. However, what is noteworthy is that there was almost no hostility resulting from the introduction of the science and religion element while the majority of the students (120 out of 202) agreed strongly or agreed with the statement "As a result of taking this course, I understand more about the relationship between science and religion/philosophy", with only 33 disagreeing.

Whether or not it is appropriate to teach students in science classes about the nature of religious knowledge as well as the nature of scientific knowledge is likely to vary from country to country (cf. Kawasaki, 1996; National Academy of Sciences, 1999), from time to time, from school to school, and even from teacher to teacher within a school (Reiss, in press). The strongest argument, in my view, for teaching anything about religion in a science class, whether at school, college or university, is if it helps students better to understand science. I am not here, therefore, addressing the more general question as to whether students should be taught in schools or college about religion for other reasons (e.g. that students should be introduced to the various domains of knowledge, one of which is religious knowledge with its distinctive claims, or because teaching about religion helps one better understand history or morality).

Teaching about aspects of religion in science classes could potentially help students better understand the strengths and limitations of the ways in which science is undertaken, the nature of truth claims in science, and the 
importance of social contexts for science. However, there are also reasons to be cautious before teaching about aspects of religion in science classes (Reiss, 1992). For example, a science teacher might feel that they simply don't have the expertise to teach effectively about such matters (though my experience and that of others is that initial teacher education and continuing professional development can help address this need), that these matters are better dealt with elsewhere in the curriculum (in some cases co-operation with other subject departments can be fruitful), or that it is impossible to teach objectively about such matters so that one risks indoctrinating one's students either into or away from a religious faith. In addition, there can be legal restraints on the extent to which religion can be discussed in classes and, more mundanely, there are frequently the constraints of curriculum time.

One approach that I have found to be of worth in science classes with undergraduates training to be science teachers is, when teaching about the nature of science, to get them to think about the relationship between scientific knowledge and religious knowledge. What seems to work well is to ask students, either on their own or in pairs, to illustrate this by means of a drawing, and then for all of us in the class to discuss the various drawings that result. See, for example, the hypothetical representation in Figure 1. A person producing the representation in Figure 1 sees both religious and scientific knowledge as existing but envisages the scope of religious knowledge as being smaller than that of scientific knowledge and of there being no overlap between the two.

A number of science educators favour a clear-cut distinction between religious and scientific knowledge, along the lines of that defended by Gould (1999). There are a number of advantages to such a position. For example, it allows a person with a strong religious belief who might otherwise be troubled by certain aspects of science to avoid possible conflict (and vice versa) and it provides an epistemological justification for why religious matters should not be examined in science classes, which is useful in a country such as the USA that prohibits the teaching of religion in public [i.e. state in the UK sense of the term] schools. 
However, there are many for whom scientific knowledge and religious knowledge are not distinct. At one end are those who draw religious knowledge as being much smaller than scientific knowledge and wholly or partly contained within it (Figure 2); at the other are those whose worldview is predominantly religious (Figure 3). Understandings of the relationship(s) between science and religion vary greatly, at least in part because of considerable variation in how people conceptualise both science and religion (Brooke, 1991). The visual metaphor in Figures 1, 2 and 3 can be taken too far but it can serve as a useful heuristic device.

\section{Teaching about controversial issues}

A widely accepted definition of a controversial issue is that "A matter is controversial if contrary views can be held on it without those views being contrary to reason" (Dearden, 1984: 86). Most people would agree that the science/religion issue is controversial both according to this definition and to the commonsense understanding of the term 'controversial', though we can note that Dearden's definition is really a definition of 'uncertainty'. Controversy surely requires that some significance be attached to the uncertainty. For example, there is uncertainty about many matters in geography (the precise heights of mountains, the sources of rivers, etc.) but little or no controversy attaches to many (though not all) such uncertainties.

For someone to say that an issue is controversial is not to mean that they themselves necessarily consider it controversial - they may hold that the matter is completely uncontroversial - but that a range of views can be held on it by people without those views being unreasonable. So, for example, the teaching of sex education, whether we should have capital punishment and the significance of global climate change are all controversial whereas the value of $\pi$, the outcome of the Second World War and whether slavery is desirable are not. 
Furthermore, an issue may be controversial at one time but not at another slavery was certainly controversial in the middle of the nineteenth century even if it is not so now (despite the fact that it still occurs in parts of the world) and I suspect that the significance of global climate change will become less controversial (but more important) as the years go by - and it is easier for us today than it was in Dearden's time to see that a matter may be controversial for some people but not others. After all, the science/religion issue is not controversial, merely exasperating, to Peter Atkins (Atkins, 1992) and Richard Dawkins. A more general point is that controversy is often neither entirely absent nor completely present; there are degrees of controversy.

Importantly, a matter can be controversial without it being scientifically controversial. There are very few professional scientists for whom the young Earth hypothesis (i.e. that the Earth is some 10,000 or fewer years old; at any rate, orders of magnitude younger than the widely accepted figure among professional scientists of around 4,600 million years) is scientifically controversial: it is simply judged to be wrong. In the same way, there are very few professional scientists for whom the theory of evolution (in the sense that all life today is presumed to derive from extremely simple ancestors and ultimately from inorganic materials) is a controversial part of science. However, this last example illustrates the fact that a scientific theory may not be controversial even though aspects of it are. For example, precisely how life evolved from inorganic materials is still very unclear and there is at least some degree of controversy about such matters as the relative importance attached to natural selection versus other agents of evolutionary change, how long it typically takes for a new species to arise and many, many details of the history of life - how one group of organisms evolved into another being chief amongst these, though we are learning more (e.g. about the origins of whales, bats and the earliest land animals) all the time.

Would one want explicitly to teach about creationism in science lessons? Both the knee-jerk and the considered reaction from most scientists and science educators has been 'no'. Here my interest in not in the legal situation that 
obtains in any one country - carefully discussed with reference to the USA by Randy Moore in a series of papers culminating in Moore (in press) - nor in the undoubted demands that teaching in this area can place on teachers (Griffith \& Brem, 2004) but in whether it would desirable on educational grounds to teach about creationism in science lessons. Given the preceding paragraph, I would not want any such teaching, were it to occur, to give the impression that creationism and the theory of evolution are equally valid scientifically. They are not (and nor is it appropriate to insist on spending equal amounts of time on evolution and creationism in science lessons).

However, I do not belong to the camp that argues that creationism is necessarily non-scientific. For all that I have no doubt that the overwhelming majority of those who believe in creationism (and intelligent design theory) do so because of their religious beliefs it is logically possible to hold that evolution (sensu major anatomical, physiological, genetic and biochemical changes in organisms over long periods of time) has not happened. I can conceive of a world in which the earliest fossils indicate creatures as complicated as ourselves and in which the same geological strata show human and dinosaur footprints. Indeed, I very much favour students examining the evidence for evolution in a critical manner.

Furthermore, I am not convinced that something being 'non-scientific' is sufficient to disqualify it from being considered in a science lesson. An understanding of (non-scientific) context often helps in learning the content of science, partly by motivating the learner, partly by indicating why the content is meaningful and partly by rendering the content more intelligible. Indeed, the distinction between context and content can be more blurred in the biological and earth sciences than in physics and chemistry. When a student learns about the cellular mechanisms and genetic principles that underlie cystic fibrosis, is cystic fibrosis at least in part the content or merely the context for membrane transport and inheritance? As far as evolution is concerned, stories about, for example, the voyage of The Beagle or the domestication of pigeons can simply be motivating for students or can also help clarify the 
thinking that Darwin went through, thus enabling students themselves better to understand the science.

An additional point is that much of the debate about the teaching of evolution is still situated, albeit implicitly, in a view of education in which the teacher has complete control over that which enters each student's mind about the issue in question. Such a view has been outmoded for years. If one turns from considering that which is taught to that which is learned, it immediately becomes clear that students have always (and nowadays possibly more than ever) learned outside of formal lessons and from people (including family) and other sources in addition to their prescribed textbooks.

This leads onto the more general point about how one should teach about controversial issues in science. The short answer is that one should do so in a way that respects evidence and valid reasoning, that helps students to understand which aspects of an issue are controversial and which are not (e.g. with reference to global warming it is not controversial that atmospheric carbon dioxide levels are rising, there is a small, though decreasing, degree of controversy attached to the role of humans in this, and there is still considerable controversy as to the impact that this rise will have for humans and other species).

As to the precise techniques one can employ when teaching a controversial issue, there are many (e.g. Wellington, 1986). I have tried, in addition to other approaches (e.g. advocacy and affirmative neutrality), the approach of procedural neutrality (in which the teacher acts as a facilitator but does not try to steer the debate in any particular direction). Graduate science students doing a one-year course to become specialist science teachers were presented with a wide range of materials detailing how Darwin's On the Origin of Species By Means of Natural Selection was received after its publication on 24 November 1859. The students then divided themselves into four groups and desk-top published the front page of a newspaper of that time reacting to Darwin's book. One group produced The Times which, though it discussed the book, gave pride of place to Garibaldi's campaign in Italy. Another group 
produced Nature which, though generally positive about the book, stressed the controversy caused in the scientific establishment. A third group produced The Church Times which gave pride of place to Lord Wilberforce's scientific assessment of Darwin's theory. Finally, the fourth group formed a feminist workers' co-operative and produced a tabloid called The Splurge. Their lead story was headed "All Men are Apes/ It's Official!!!".

\section{Teaching about matters of personal significance}

Even if one agrees that there are aspects of the science/religion issue that can or should validly be taught in science lessons, this is not to minimize the fact that teaching about this relationship is, for many, a matter of considerable personal significance. Teaching about a matter of personal significance is related to but not identical to teaching about a controversial issue. To teach about matters of personal significance can demand much of us as teachers. It exposes aspects of ourselves to our students in a way which many teachers will find threatening or invasive, though some may find exciting. There are parallels to teaching about ourselves as sexual beings when teaching sex education - a dangerous state of affairs and one that I caution new entrants to the teaching profession to avoid, at the least for their own sakes.

Equally, teaching about matters of personal significance can make significant demands on students (Jackson et al., 1995; Dagher \& BouJaoude, 1997; Roth \& Alexander, 1997; Downie \& Barron, 2000). We need to find ways that are respectful of students, that neither threaten their beliefs nor molly coddle them as if getting them to think about their beliefs was necessarily to attack them. In England and Wales, a course for 16-19 year-olds that I direct, titled Salters-Nuffield Advanced Biology, has been running in a pilot version since September 2002 and nationally since September 2005. One of the learning objectives in the topic on evolution and ecology is "Appreciate why, for cultural reasons, the theory of evolution has been so controversial for some people" (Edexcel, 2005: 31). The reason for including this learning objective is because the team devising the course felt it worthwhile for 16-19 year-olds to 
understand something about this issue Of course, the aim is neither to persuade students to embrace certain religious beliefs nor to cause them to abandon them: it is to help them learn and to clarify their thinking. The material in the student textbook that relates to this learning objective is quoted in Box 1.

Almost everyone reading Box 1 can probably find something in it that they don't like. However, our purpose in writing it was to avoid shying away from the science/religion issue and to attempt to present material that would not be considered unfair or disrespectful by readers, whatever their own positions on the issue. There is an optional activity that teachers have available to help them when teaching this part of the course. This activity is a role play for students, and the student sheet that accompanies it is presented in Box 2 .

Part of the hope would be, as it often is with role plays, that undertaking this activity, and the subsequent classroom discussion, would help students better to understand one another and that this understanding might help them to respect views other than their own.

\section{CONCLUSION}

The science/religion issue generates a great deal of heat (Scharmann, 1993; Park, 2001; Allgaier, 2005; Gauld, 2005; Pigliucci, 2005; Skoog, 2005). I have examined here the nature of the issue both in general terms and with reference to particular topics. I have argued that there are good reasons for students being introduced to aspects of the science/religion issue in science lessons. Such teaching is not easy but done well it can be respectful of students, motivating and fulfilling for them and help them to learn more about the nature and content of science.

At the same time, and finally, a great deal more work could profitably be undertaken in this area. A whole host of research questions suggest themselves. What precisely should be the aims of teaching in this area? Are 
science/religion issues core or peripheral to science education? What are the best ways of addressing these issues in the science classroom? How much knowledge of religion does a science educator need? How great is the range of religions that might need to be addressed in the science classroom? What initial teacher education and continuing professional development in this area is most effective for science teachers? How much time (if any) should be spent on the science/religion issue and to what extent is the answer to this question dependent on the particular science educator? If the issue is to be addressed, what facets should be considered for different ages of students?

Not all of these questions are empirical and of those that are, a range of methodologies can be envisaged (including ethnographic work, surveys, longitudinal research and action research). My hope is that future work will address these and related questions without losing sight of the twin truths that the main function of science education is to help students learn science and that for the majority of students who come to science lessons, science plays only a small part in their lives.

\section{ACKNOWLEDGEMENTS}

I am extremely grateful to three referees and to Jim Donnelly for valuable feedback on an earlier version.

\section{REFERENCES}

ALLGAIER, J. (2005). Opening up the controversy about teaching creation/evolution, Pantaneto, 17. Available at http://www.pantaneto.co.uk/issue17/allgeier (last accessed 28 July 2006).

AL-HAYANI, F.A. (2005). Islam and science: contradiction or concordance, Zygon, 40, 565-576.

ATKINS, P. (1992). Will science ever fail? New Scientist, 8 August, 32-35. 
AYALA, F.J. (2006). Darwin and Intelligent Design. Minneapolis: Fortress Press.

BAKER, S. (2003). Bone of Contention: Is evolution true?, $3^{\text {rd }}$ edn. Rugby: Biblical Creation Society.

BARBOUR, I.G. (1990). Religion in an Age of Science: The Gifford Lectures 1989-1991, volume 1. London: SCM.

BATCHELOR, M. \& BROWN, K. (Eds) (1992). Buddhism and Ecology. London: Cassell

BEHE, M.J. (1996). Darwin's Black Box: The biochemical challenge to evolution, New York: Free Press.

BEHE, M. (2003). The modern intelligent design hypothesis: breaking rules. In: God and Design: The teleological argument and modern science, Manson, N.A. (Ed.), London: Routledge, pp. 277-291.

BENTLEY, M.L. (2000). Improvisational drama and the nature of science, Journal of Science Teacher Education, 11, 63-75.

BERRY, A.C. (1992). Genetic engineering and medical treatment. In Genetic Engineering: Christian Responsibilities in God's World: A conference organised by Christians in Science and the Christian Medical Fellowship, Paper 2. London: Christian Medical Fellowship.

BERRY, R.J. (1988). God and Evolution. London: Hodder \& Stoughton. BOWKER, J. (1995). Is God a Virus? Genes, Culture and Religion: The Gresham Lectures, 1992-3. London: SPCK.

BRADLEY, I. (1990). God is Green: Christianity and the environment. London: Darton, Longman and Todd.

BROOKE, J.H. (1991). Science and Religion: Some historical perspectives. Cambridge: Cambridge University Press.

BROWER, D. (Friends of the Earth) (1987). Interview with San Francisco Chronicle, quoted in Jukes, T.H. (1988). Hazards of biotechnology: facts and fancy, Journal of Chemical Technology and Biotechnology, 43, p249.

BROWN, B.E. (2004). Environmental ethics and cosmology: a Buddhist perspective, Zygon, 39, 885-900.

BRUCE, D. \& BRUCE, A. (Eds) (1998) Engineering Genesis: The ethics of genetic engineering in non-human species. London: Earthscan. 
CAMPBELL, J.A. \& MEYER, S.C. (Eds) (2003). Darwinism, Design, and Public Evolution. East Lansing, Michigan: Michigan State University Press.

CHALMERS, A.F. (1999). What is this Thing called Science?, $3^{\text {rd }}$ edn. Buckingham: Open University Press.

CHALLIS, P. (1992). Genetic Engineering and its Applications: Some theological and ethical reflections, Cambridge: Wesley House.

CHAPPLE, C. (1994). Contemporary Jaina and Hindu responses to the ecological crisis. In An Ecology of the Spirit: Religious reflection and environmental consciousness, Barnes, M. (Ed.), Lanham: University Press of America, pp. 209-218.

CLANCY, S.A. (2005). Abducted: How people come to believe they were kidnapped by aliens. Cambridge, Massachusetts: Harvard University Press.

CLOUGH, M.P. (1994). Diminish students' resistance to biological evolution, American Biology Teacher, 56, 409-415.

COBERN, W. (1996). Worldview theory and conceptual change in science education, Science Education, 80, 579-610.

COLBURN, A. \& HENRIQUES, L. (2006). Clergy views on evolution, creationism, science, and religion. Journal of Research in Science Teaching, 43, 419-442.

COLE-TURNER, R. (1993). The New Genesis: Theology and the genetic revolution. Louisville, Kentucky: Westminster / John Knox Press.

DAGHER, Z.R. \& BOUJAOUDE, S. (1997). Scientific views and religious beliefs of college students: the case of biological evolution, Journal of Research in Science Teaching, 34, 429-445.

DARWIN, C. (1859). On the Origin of Species by means of Natural Selection, or the Preservation of Favoured Races in the Struggle for Life. London: John Murray.

DAWKINS, R. (1986/1988). The Blind Watchmaker. London: Penguin.

DAWKINS, R. (1993/2003/2004). A Devil's Chaplain: Selected essays. London: Phoenix.

DAWKINS, R. (1998). Unweaving the Rainbow: Science, delusion and the appetite for wonder. London: Penguin. 
DAWKINS, R. (2006). The God Delusion. London: Bantam Press.

DEANE-DRUMMOND, C. (1997). Theology and Biotechnology: Implications for a new science. London: Geoffrey Chapman.

DEANE-DRUMMOND, C. (2001). Biology and Theology Today: Exploring the boundaries. London: SCM Press.

DEARDEN, R.F. (1984). Theory and Practice in Education. London: Routledge \& Kegan Paul.

DEMBSKI, W.A. (1998). The Design Inference: Eliminating chance through small probabilities. Cambridge: Cambridge University Press.

DEMBSKI, W. (2003). The chance of the gaps. In: God and Design: The teleological argument and modern science, Manson, N.A. (Ed.), London: Routledge, pp. 251-274.

DENNETT, D.C. (2006). Breaking the Spell: Religion as a natural phenomenon. London: Allen Lane.

DeWITT, C.B. (1994). Earth-Wise: A biblical response to environmental issues. Grand Rapids, Michigan: CRC Publications.

DOWNIE, J.R. \& BARRON, N.J. (2000). Evolution and religion: attitudes of Scottish first year biology and medical students to the teaching of evolutionary biology, Journal of Biological Education, 34, 139-146.

DUVEEN, J. \& SOLOMON, J. (1994). The great evolution trial: use of roleplay in the classroom, Journal of Research in Science Teaching, 31, 575-582.

EDEXCEL (2005). AS/A GCE in Biology (Salters-Nuffield): Specification. Available at http://www.edexcel.org.uk/VirtualContent/72372/Biology Salters Nuffie Id 80489048 spec.pdf (last accessed 16 April 2006).

EVANS, E.M. (2000). Beyond Scopes: why creationism is here to stay. In Imagining the Impossible: Magical, scientific, and religious thinking in children, Rosengren, K.S., Johnson, C.N. \& Harris, P.L. (Eds), Cambridge: Cambridge University Press, pp. 305-333.

GAULD, C.F. (2005). Habits of mind, scholarship and decision making in science and religion, Science \& Education, 14, 291-308. 
GIFFORD LECTURES (2006). Overview: history of the Gifford Lectures, http://www.giffordlectures.org/overview.asp (last accessed 24 June 2006).

GOOD, R.G., TROWBRIDGE, J.E., DEMASTES, S.S., WANDERSEE, J.H., HAFNER, M.S. \& CUMMINS, C.L. (Eds) (1992). Proceedings of the 1992 Evolution Education Research Conference. Baton Rouge:

Louisiana State University.

GOULD, S.J. (1999). Rocks of Ages: Science and religion in the fullness of life. New York: Ballantin.

GRIFFITH, J.A. \& BREM, S.K. (2004) Teaching evolutionary biology: pressures, stress, and coping, Journal of Research in Science Teaching, 41, 791-809.

GROSNICK, W. (1994). The Buddahood of the grasses and the trees: ecological sensitivity or scriptural misunderstanding? In An Ecology of the Spirit: Religious reflection and environmental consciousness, Barnes, M. (Ed.), Lanham: University Press of America, pp. 197-208.

HALL, A., REISS, M., ROWELL, C. \& SCOTT, A. (Eds) (2006). SaltersNuffield Advanced Biology: A2. Oxford: Heinemann.

HALL, M. \& HALL, S. (1975). The Truth: God or evolution? Grand Rapids, Michigan: Baker Book House.

HAYWARD, A. (1985). Creation and Evolution: The facts and fallacies. London: Triangle.

HEIDEGGER, M. (1977). The Question Concerning Technology and Other Essays. Translated and with an Introduction by William Lovitt. New York: Harper Colophon.

HEINZE, T. F. (1973). Creation vs. Evolution, $2^{\text {nd }}$ revised edn. London: Pickering \& Inglis.

HELGESON, L.J., HOOVER, J. \& SHEEHAN, J. (2002). Introducing preservice teaches to issues surrounding evolution and creationism via a mock trial, Journal of Elementary Science Education, 14(2), 11-24.

HICK, J. (1976/1985). Death and Eternal Life. Basingstoke: Macmillan. HINDE, R.A. (1999). Why Gods Persist: A scientific approach to religion. London: Routledge. 
HINNELLS, J. R. (1991). A Handbook of Living Religions. London: Penguin Books.

HITCHING, F. (1982). The Neck of the Giraffe or Where Darwin Went Wrong. London: Pan.

INGRAM, E.L. \& NELSON, C.E. (2006). Relationship between achievement and students' acceptance of evolution or creation in an upper-level evolution course. Journal of Research in Science Teaching, 43, 7-24.

INTERACADEMY PANEL ON INTERNATIONAL ISSUES (2006). IAP Statement on the Teaching of Evolution. Available at http://www.interacademies.net/Object.File/Master/6/150/Evolution\%20st atement.pdf (last accessed 28 July 2006).

JACKSON, D.F., DOSTER, E.C., MEADOWS, L. \& WOOD, T. (1995). Hearts and minds in the science classroom: the education of a confirmed evolutionist, Journal of Research in Science Teaching, 32, 585-611. JOHNSON, P.E. (1999). The wedge: breaking the modernist monopoly on science, Touchstone, 12(4), 18-24.

JONES, L. \& REISS, M.J. (Eds) (In press). Teaching about Scientific Origins: Taking account of creationism. New York: Peter Lang.

KAWASAKI, K. (1996). The concepts of science in Japanese and Western education, Science \& Education, 5, 1-20.

KENNEDY, M.M. (1998). Education reform and subject matter knowledge, Journal of Research in Science Teaching, 35, 249-263.

KHALID, F. \& O'BRIEN, J. (Eds) (1992). Islam and Ecology. London: Cassell. KITCHER, P. (1983). Abusing Science: The case against creationism. Milton Keynes: Open University Press.

KOUL, R. (2003). Revivalist thinking and student conceptualizations of science/religion. Studies in Science Education, 39, 103-124.

KUHN, T.S. (1970). The Structure of Scientific Revolutions, $2^{\text {nd }}$ edn. Chicago: University of Chicago Press.

LAKATOS, I. (1978). The Methodology of Scientific Research Programmes. Cambridge: Cambridge University Press.

LANGFORD, M. (1981). Providence. London: SCM.

LARSON, E.J. \& WITHAM, L. (1999). Scientists and religion in America, Scientific American, September, 78-83. 
LEE, B.Y. \& NEWBERG, A.B. (2005). Religion and health: a review and critical analysis, Zygon, 40, 443-468.

MACBETH, N. (1974). Darwin Retried. London: Garnstone Press.

McGRATH, A. (2005). Dawkins' God: Genes, memes, and the meaning of life. Malden, Massachusetts: Blackwell.

McGRATH, A. with McGRATH, J.C. (2007). The Dawkins Delusion? Atheist fundamentalism and the denial of the divine. London: SPCK.

MABUD, S.A. (1991). Theory of Evolution: An assessment from the Islamic point of view. Cambridge; The Islamic Academy.

MANSON, N.A. (Ed.) (2003). God and Design: The teleological argument and modern science. London: Routledge.

MERTON, R.K. (1973). The Sociology of Science: Theoretical and empirical investigations. Chicago: University of Chicago Press.

MILLER, J.D., SCOTT, E.C. \& OKAMOTO, S. (2006). Public acceptance of evolution. Science, 313, 765-766.

MOORE, R. (in press). The history of the creationism/evolution controversy and likely future developments. In Teaching about Scientific Origins: Taking account of creationism, Jones, L. \& Reiss, M.J. (Eds), New York: Peter Lang.

NATIONAL ACADEMY OF SCIENCES (1999). Science and Creationism: A view from the National Academy of Sciences, $2^{\text {nd }}$ edn. Washington, DC: National Academy Press.

NEGUS, M.R. (2005). Islam and science. In God, Humanity and the Cosmos, $2^{\text {nd }}$ edn revised and expanded as $A$ Companion to the Science-Religion Debate, Southgate, C. (Ed.), London: T \& T Clark, pp. 321-339.

NUMBERS, R.L. \& STENHOUSE, J. (2000). Antievolution in the Antipodes: from protesting evolution to promoting creationism in New Zealand, British Journal for the History of Science, 33, 335-350.

OSBORN, L. (2005). Theology and the new physics. In God, Humanity and the Cosmos, $2^{\text {nd }}$ edn revised and expanded as A Companion to the Science-Religion Debate, Southgate, C. (Ed.), London: T \& T Clark, pp. 119-153.

PANNENBERG, W. (2006). Problems between science and theology in the course of their modern history, Zygon, 41, 105-112. 
PARK, H.-J. (2001). The creation-evolution debate: carving creationism in the public mind, Public Understanding of Science, 10, 173-186.

PASSMORE, C., STEWART, J. \& ZOELLNER, B. (2005). Providing high school students with opportunities to reason like evolutionary biologists, American Biology Teacher, 67, 214-221.

PEACOCKE, A.R. (1979). Creation and the World of Science: The Bampton Lectures, 1978. Oxford: Clarendon Press.

PEACOCKE, A. (2001). Paths from Science towards God: The end of all our exploring. Oxford: Oneworld.

PIGLIUCCI, M. (2005). Science and fundamentalism: a strategy on how to deal with anti-science fundamentalism. EMBO reports, 6, 11-6-1109.

PLIMMER, I. (1994). Telling Lies for God: Reason vs creationism. Milsons Point, NSW: Random House Australia.

POLKINGHORNE, J. (1994). Science and Christian Belief: Theological reflections of a bottom-up thinker. The Gifford Lectures for 1993-4. London: SPCK.

POLKINGHORNE, J. (2005). The continuing interaction of science and religion, Zygon, 40, 43-50.

POLKINGHORNE, J. (2006). Where is natural theology today? Science \& Christian Belief, 18, 169-179.

POOLE, M.W. (1994). A critique of aspects of the philosophy and theology of Richard Dawkins, Science \& Christian Belief, 6, 41-59.

POOLE, M. (1995). Beliefs and Values in Science Education. Buckingham: Open University Press.

POOLE, M.W. (2002). Explaining or explaining away? The concept of explanation in the science-theology debate, Science \& Christian Belief, 14, 123-142.

POPPER, K.R. (1934/1972). The Logic of Scientific Discovery. London: Hutchinson.

PRIME, R. (1992). Hinduism and Ecology: Seeds of truth. London: Cassell. RAY, J. (1691/2005). The Wisdom of God Manifested in the Works of the Creation. London: Ray Society. 
REISS, M.J. (1992). How should science teachers teach the relationship between science and religion? School Science Review, 74(267), 126130.

REISS, M.J. (1993). Science Education for a Pluralist Society. Milton Keynes: Open University Press.

REISS, M.J. (2002). Reforming school science education in the light of pupil views and the boundaries of science. School Science Review, 84(307), 71-77.

REISS, M.J. (2003). Is it right to move genes between species? A theological perspective. In Re-ordering Nature: Theology, Society and the New Genetics, Deane-Drummond, C. \& Szersynski, B. with Grove-White, R. (Eds), London: T. \& T. Clark, pp. 138-150.

REISS, M. (2005). The nature of science. In Learning to Teach Science in the Secondary School: A companion to school experience, $2^{\text {nd }}$ edn, Frost, J. \& Turner, T. (Eds), London: RoutledgeFalmer, pp. 44-53.

REISS, M.J. (in press). Teaching about origins in science - where now? In Teaching about Scientific Origins: Taking account of creationism, Jones, L. \& Reiss, M.J. (Eds), New York: Peter Lang.

REISS, M.J. \& STRAUGHAN, R. (1996). Improving Nature? The science and ethics of genetic engineering. Cambridge: Cambridge University Press. REYNOLDS, V \& TANNER, R.E.S. (1983) The Biology of Religion. London: Longman.

ROLLIN, B.E. (2005). Genetic engineering and the sacred, Zygon, 40, 939951.

ROSE, A. (1992). Judaism and Ecology. London: Cassell

ROSZAK, T. (2004). God and the final frontier. New Scientist, 28 March, 4041.

ROTH, W.-M. \& ALEXANDER, T. (1997). The interaction of students' scientific and religious discourses: two case studies, International Journal of Science Education, 19, 125-146.

RUSE, M. (2005). The Evolution-Creation Struggle. Cambridge, Massachusetts: Harvard University Press.

SAUNDERS, N. (2002). Divine Action and Modern Science. Cambridge: Cambridge University Press. 
SCHARMANN, L.C. (1993). Teaching evolution: designing successful instruction, American Biology Teacher, 55, 481-486.

SCIENCE AND RELIGION IN SCHOOLS PROJECT (2006). Science and Religion in Schools. Oxford: Millwood Education Trust. (Information including sample materials available at www.srsp.net/.)

SELKIRK, D.R. \& BURROWS, F.J. (Eds) (1987). Confronting Creationism: Defending Darwin. Kensington, NSW: New South Wales University Press.

SHIELDS, M. (2004). Are humans still evolving? A natural selection discussion lesson, American Biology Teacher, 66, 21-25.

SHIPMAN, H.L., BRICKHOUSE, N.W., DAGHER, Z. \& LETTS, W.J.IV (2002). Changes in student views of religion and science in a college astronomy course, Science Education, 86, 526-547.

SKEHAN, J.W. \& NELSON, C.E. (Eds) (2000). The Creation Controversy \& The Science Classroom. Arlington: NSTA Press.

SKOOG, G. (2005). The coverage of human evolution in high school biology textbooks in the 20th century and in current state science standards, Science \& Education, 14, 395-422.

SMART, N. (1989). The World's Religions: Old traditions and modern transformations. Cambridge: Cambridge University Press.

SMITH, M.U. (1994). Counterpoint: belief, understanding, and the teaching of evolution, Journal of Research in Science Teaching, 31, 591-597.

SOUTHGATE, C., NEGUS, M.R. \& ROBINSON, A. (2005) Theology and evolutionary biology. In God, Humanity and the Cosmos, $2^{\text {nd }}$ edn revised and expanded as A Companion to the Science-Religion Debate, Southgate, C. (Ed.), London: T \& T Clark, pp. 154-192.

SZERSZYNSKI, B. (2005). Rethinking the secular: science, technology, and religion today, Zygon, 40, 813-822.

TANAHASHI, K. (Ed.) (1988). Dogon: Moon in a dewdrop. Shaftesbury: Element Books.

THICH NHAT HANH (1988). The Sun My Heart. Berkeley: Parallax Press. TOULMIN, S. (1972). Human Understanding (Vol. I). Princeton, NJ: Princeton University Press.

WATSON, D.C.C. (1975). The Great Brain Robbery. Worthing: Henry E. 
Walter.

WATTS, F. (Ed.) (1998). Science Meets Faith. London: SPCK.

WCC (1990). Giver of Life - Sustain Your Creation: Report of the pre-

assembly consultation on sub-theme 1. Kuala Lumpur, Malaysia.

WELLINGTON, J.J. (Ed.) (1986). Controversial Issues in the Curriculum.

Oxford: Basil Blackwell.

WHITE, A.J.M. (1978). What About Origins? Newton Abbot: Dunestone.

WILLIAMS, P.A. (2001). Doing Without Adam and Eve: Sociobiology and original sin. Minneapolis, MN: Fortress Press.

YEARLEY, S. (2005). Making Sense of Science: Understanding the social study of science. London: SAGE.

ZIMAN, J. (2000). Real Science: What it is and what it means. Cambridge: Cambridge University Press.

\section{Contact details}

Institute of Education

University of London

20 Bedford Way

London WC1H OAI

UK

E-mail: $\underline{\text { m.reiss@ioe.ac.uk }}$ 

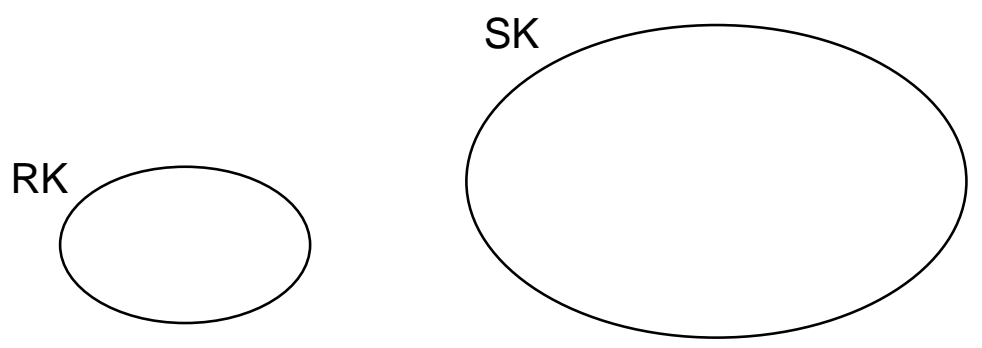

Figure 1 Hypothetical representation of how someone who sees both religious and scientific knowledge as existing but envisages the scope of religious knowledge as being smaller than that of scientific knowledge and of there being no overlap between the two might draw the relationship between religious knowledge (RK, left) and scientific knowledge (SK, right). 


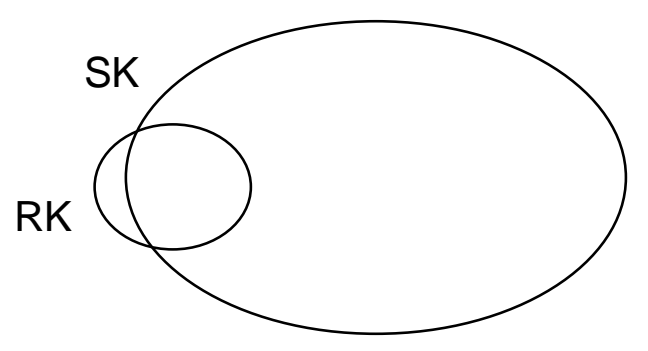

Figure 2 Hypothetical representation of how someone who sees religious knowledge as being much smaller than scientific knowledge and almost entirely contained within it might draw the relationship between religious knowledge (RK) and scientific knowledge (SK). 


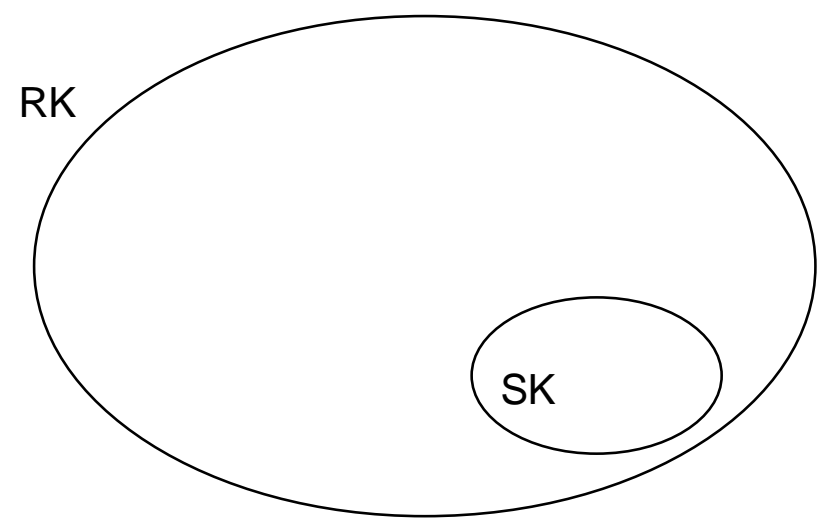

Figure 3 Hypothetical representation of how someone whose worldview is predominantly religious might draw the relationship between religious knowledge (RK) and scientific knowledge (SK). 


\section{Why is the theory of evolution controversial?}

Darwin had considered training to be a clergyman and knew that his ideas about evolution meant that he seemed to be challenging the Bible. The first two chapters of Genesis record how all of the Earth's organisms were created by God about 6000 to 10000 years ago, in much the form that they exist today.

It is hard for many people to appreciate just how controversial Darwin's ideas were at the time. To this day there are many people in the world who cannot reconcile their religious beliefs and the theory of evolution. Few Muslims accept it and many Christians either reject or aren't comfortable with it either. In the UK around $10 \%$ of people are creationists. Creationists accept the literal teaching of the Bible, Qur'an or other scriptures and reject the theory of evolution. Creationists believe, for example, that God specially created Adam and Eve out of the dust of the earth so that humans are quite distinct from all other species. In the USA around $40 \%$ of people are creationists. Indeed, worldwide there is no doubt that the idea that all organisms are descended from a common ancestor that lived some 3000 million years ago - which is what evolutionary biologists believe - is a minority position.

The great majority of biologists, geologists and other scientists do accept a modernised version of evolution called neo-Darwinism. Neo-Darwinism combines Darwin's and Wallace's theory of natural selection with what we now know about inheritance. Many scientists who accept the theory of evolution in this modernised version also have firm religious beliefs. Such scientists have various ways of reconciling their religious beliefs with the theory of evolution. For example, they may believe that God created the original conditions that enabled the universe to come into existence, and then allowed evolution to take its course. In this understanding, God gives the whole of creation, including us, a certain freedom. Life is not predetermined but open ended.

Box 1 Extract from the Salters-Nuffield Advanced Level course (Hall et al., 2006: 51) 


\section{Activity 5.16 The controversial nature of the theory of evolution}

This activity gets you to engage in a discussion to help you understand why, for cultural reasons, the theory of evolution has been so controversial for some people. In groups you and your peers will engage in a modest role play in which you defend a range of positions with respect to the evolutioncreationism debate. Each of you will have one of the four roles outlined below.

This may be an issue about which you have thought carefully or not at all. The aim of the activity is not necessarily to get you to change your own views but to appreciate how different people can hold different views on this issue.

\section{Atheist with a strong belief in evolutionary biology}

You have spent a reasonable amount of time thinking about religion and are certain that there is absolutely no truth in any religious claims. You are happy to describe yourself, if asked, as an atheist. You don't try and force your views on others but intensely dislike and consider wholly unjustified any attempt by someone with a religious faith to convert others to their point of view.

You think the world would be a better place without religions. What you particularly dislike is the way in which religious people seem certain that their view is right. You are extremely dubious about the extent to which anyone with a religious faith can be a decent scientist.

One of the exciting things about evolutionary biology, you feel, is the way in which it can explain, through natural selection, why people have a religious faith. You haven't had time to read the latest books on the subject but know that the authors argue that religions evolved to make people more likely to be altruistic and get along with their neighbours. This would have had survival value.

\section{Agnostic}

You haven't really given much thought as to whether there is a God or not and feel you have an open mind on the question. You rather wish more people were prepared to have an open mind about such matters as it seems to you that half the world's problems are caused by people being so certain about things of which they know rather little.

\section{Religious belief and belief in evolutionary biology}

You have a strong religious faith and are pretty sure that the conventional evolutionary biology account is correct. It rather frustrates you that most people seem unable to read the scriptures in any way other than the more literal fashion. Whether or not miracles occurred in the past they don't seem to nowadays much, if at all, and, anyway, the important thing about the 
scriptures is not the miracles they describe but the way they point to the nature of God and to what it is to lead a flourishing life.

You feel strongly that the combination of a strong religious faith and a belief in evolutionary biology is the best way to understand human nature.

Evolutionary biology is concerned with factual questions of how life (including humans) evolved. Religion is concerned with ultimate questions of value and being.

\section{Creation scientist}

You have a strong religious faith and accept the scientific method. However, you don't think that the scientific evidence points to an old Earth; quite the opposite. You feel that the scientific account that makes the most sense is that life arose on Earth round about 10000 years ago and soon after was almost totally destroyed by a giant flood. What science cannot do is to say why these events occurred: this is provided by scripture.

You think that it is a really good idea for advanced level biology students to examine critically the evidence for evolution and feel confident that if they are given the time to do this, many of them will realise that evolution is confined to natural selection within species or possibly leading to the evolution of closely related species over a period of a few thousand years.

Box 2 Extract from the Salters-Nuffield Advanced Level course (www.snabonline.com/; last accessed 16 April 2006; password protected). 